\title{
New aerophytic morphospecies of Nostoc (Cyanobacteria) from São Paulo State, Brazil
}

\author{
Célia Leite Sant'Anna ${ }^{1,4}$, Maria Teresa de Paiva Azevedo ${ }^{1}$, Luis Henrique Zanini Branco ${ }^{2}$ and Jiří Komárek ${ }^{3}$ \\ Received: 17.08.2006; accepted: 03.01.2007
}

\begin{abstract}
New aerophytic morphospecies of Nostoc (Cyanobacteria) from São Paulo State, Brazil). Brazilian aerophytic biotopes are almost completely unknown regarding to cyanobacterial flora. During the study of this special flora, three morphospecies of the genus Nostoc from different habitats in the State of São Paulo, Brazil, were found. Based on their morphology, especially by formation and shape of the akinetes, life cycles and ecology, these populations were considered distinct from all known taxa of Nostoc and are proposed as new species: N. interbryum, N. viride, and N. alatosporum.

Key words: Brazil, Cyanobacteria, new species, Nostoc
\end{abstract}

RESUMO - (Novas morfoespécies aerofíticas de Nostoc (Cyanobacteria) do Estado de São Paulo, Brasil). Ambientes aerofíticos brasileiros são quase totalmente desconhecidos em relação à sua flora de cianobactéria. Durante o estudo desta flora, três morfoespécies do gênero Nostoc foram encontradas em diferentes habitats do Estado de São Paulo, Brasil. Com base na morfologia, especialmente na formação e forma dos acinetos, no ciclo de vida e na ecologia, estas populações foram consideradas distintas de todos os demais taxons de Nostoc e são propostas como espécies novas: N. interbryum, N. viride, and N. alatosporum.

Palavras-chave: Brasil, Cyanobacteria, espécies novas, Nostoc

\section{Introduction}

The modern cyanobacterial taxonomic studies are based mostly on the combined phenotypical, ultrastructural, ecological and molecular data. However, particularly in extreme tropical biotopes, morphological studies and detailed investigation of its biodiversity remain very little known. On that account, descriptions of evidently new morpho and ecospecies are very important for recognition of cyanobacterial diversity under natural conditions.

Studies of aerophytic cyanobacteria from tropical and subtropical habitats in the State of São Paulo, Brazil, started only recently. In numerous special habitats, such as wet rocks, bark of trees in rainy forest, and wet lateritic soils, several special morphotypes occur, which do not correspond to any described species. Their cultivation is difficult and, consequently, the description of such natural populations is very important for future research. Thus, during the development of these studies, three new morphospecies corresponding with the genus Nostoc, were found in different habitats.

The genus Nostoc comprises around 200 species mostly growing in benthonic communities of lakes or in aerophytic habitats (Komárek et al. 2003). In spite of this great number of species, the Brazilian literature mentions only eight species of Nostoc, most part living in aerophytic habitats. These species do not correspond morphologically and ecologically to the studied populations which display a group of characteristics that makes them perfectly distinct from all species of Nostoc described up to now.

\section{Material and methods}

Samples were collected scraping the substrate with spatula. The preservation of samples was done using formaldehyde. The study of natural populations was carried out through optical microscopy and it was

1. Instituto de Botânica, Caixa Postal 3005, 01061-970 São Paulo, SP, Brasil

2. Universidade Estadual Paulista "Júlio de Mesquita Filho", Instituto de Biociências, Departamento de Zoologia e Botânica, Rua Cristóvão Colombo 2265, 15054-000 São José do Rio Preto, SP, Brasil

3. Academy of Sciences of the Czech Republic, University of South Bohemia, Institute of Botany, Faculty of Biological Sciences, Branišovská 31, CZ-370 05 České Budějovice, Czech Republic

4. Corresponding author: celiasant@ig.com.br 
based on the analyze of 20 specimens at least. The structure of mucilage was observed using China Ink. The classification system of Komárek \& Anagnostidis (1989) was adopted.

\section{Results}

Nostoc interbryum C.L. Sant'Anna et al. sp. nov. Figures 1, 4-5

Coloniae microscopicae, sphaericae, cum trichomatibus curtis, ad 30-cellulis, arcuatis vel paucim flexuosis, moniliformibus, ad genicula clare constricta, dense intricata, 4-5 $\mu$ m latis, ad apices not attenuatis; mucilago coloniarum sine colore vel lutescente, superficie peridermo firmo circumdata. Cellulae breve dolliformibus vel sphaericae, 2.6$4.2 \mu \mathrm{m}$ longae, contentu pallide griseo-aerugineo. Heterocytis sphaericis vel subsphaericis, 4-4.8 $\times$
4-5.2 $\mu \mathrm{m}$. Sporis ovalibus, in seriebus curtis, 6-8 cellulae, contentu granuloso, superficie leves, 5-7 $\times$ 4.5-5 $\mu \mathrm{m}$, episporio greiseo-nigro.

Typus: BRAZIL. SÃo Paulo: Campos de Jordão, "Horto Florestal", 22 $41^{\circ} 26^{\prime}$ "S and $45^{\circ} 28^{\prime} 51$ "W, 9-XI-2002, C.L. Sant'Anna, M.T.P. Azevedo and J. Komárek s.n. (holotype SP365670).

Colonies microscopic, almost spherical, enveloped by firm, delimited, colourless or slightly yellowish sheath, with periderm. Filaments moniliform, short, up to 30 cells, slightly coiled or curved. Cells shortly barrel-shaped to almost spherical, 4-5 $\mu \mathrm{m}$ wide, 2.6-4.2 $\mu \mathrm{m}$ long. Cell content homogeneous, pale bluegreyish. Heterocytes mainly terminal, usually at one end of trichomes, rarely intercalar, slightly wider than vegetative cells, 4-5.2 $\mu \mathrm{m}$ wide, 4-4.8 $\mu \mathrm{m}$ long. Akinetes in chains from short trichomes (up to 6-8-

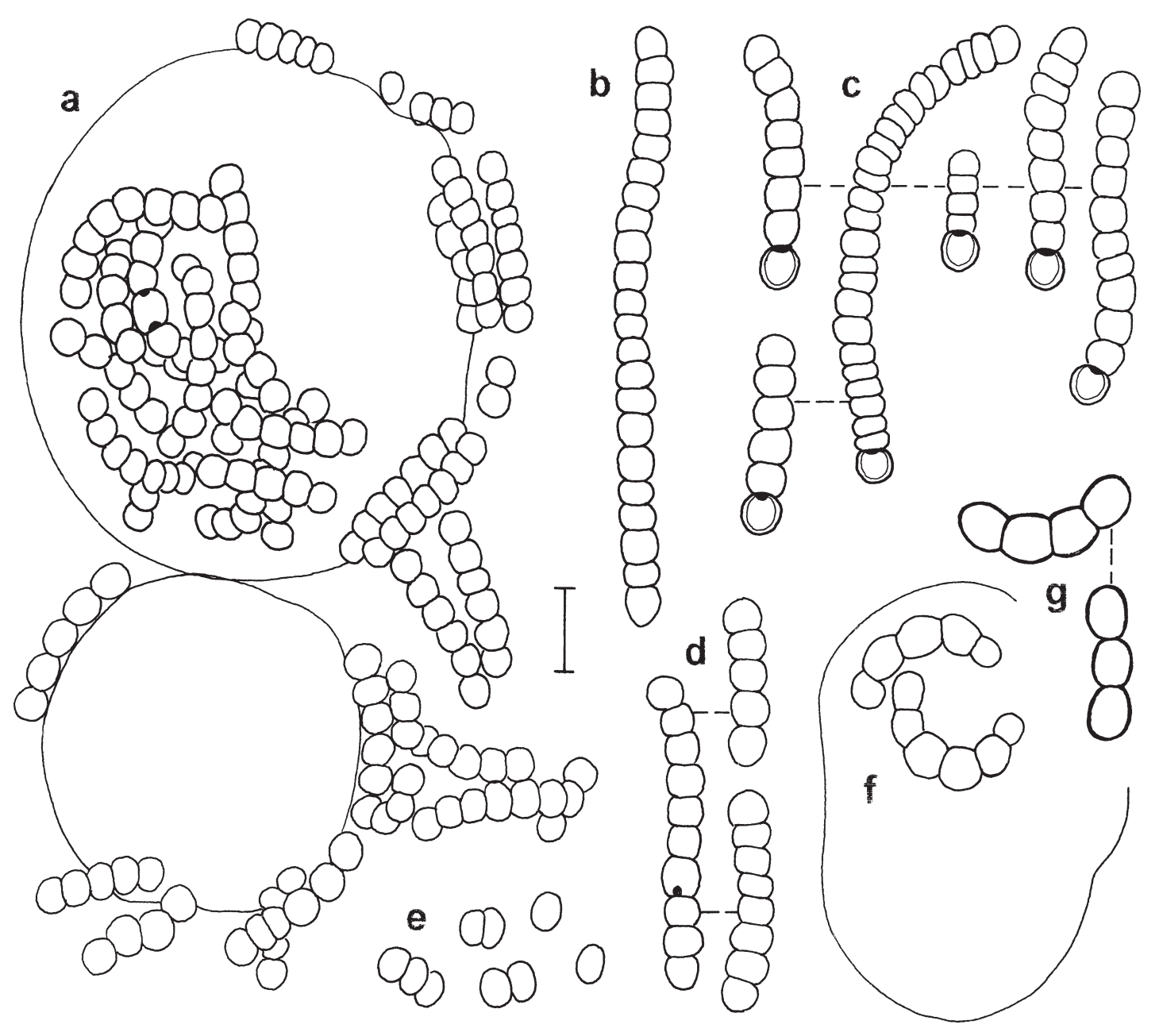

Figure 1a-g. Nostoc interbryos. a. Two colonies with escaped hormogonia. b. Filament without heterocyte. c. Filaments with terminal heterocytes. d. Hormogonia. e. Reproduction unicells and few-celled hormogonia. f. Splitted mucilaginous periderm with short filamens changing in akinetes. g. Short chaines of akinetes. Scale bar $=10 \mu \mathrm{m}$. 
celled), slightly lengthways oval, 5-7 $\mu \mathrm{m}$ long, 4.5-5 $\mu \mathrm{m}$ wide, with homogeneous, slightly granular content, dark grey epispore. Reproduction by hormogonia, up to 8-celled, which escape from the sheath and creep over the wet natural substrata (sheaths from outside, bark, mosses). Disintegration of trichomes in solitary cells was also commonly observed.
Habitat: colonies growing on bark of trees in rainy forest, mainly among epiphytic mosses and liverworth.

Nostoc viride C.L. Sant'Anna et al. sp. nov.

Figures 2, 6-7

Coloniae macroscopicae, ad plures $\mathrm{cm}$ in diametro, strata mucilaginosa, praecipue amorpha

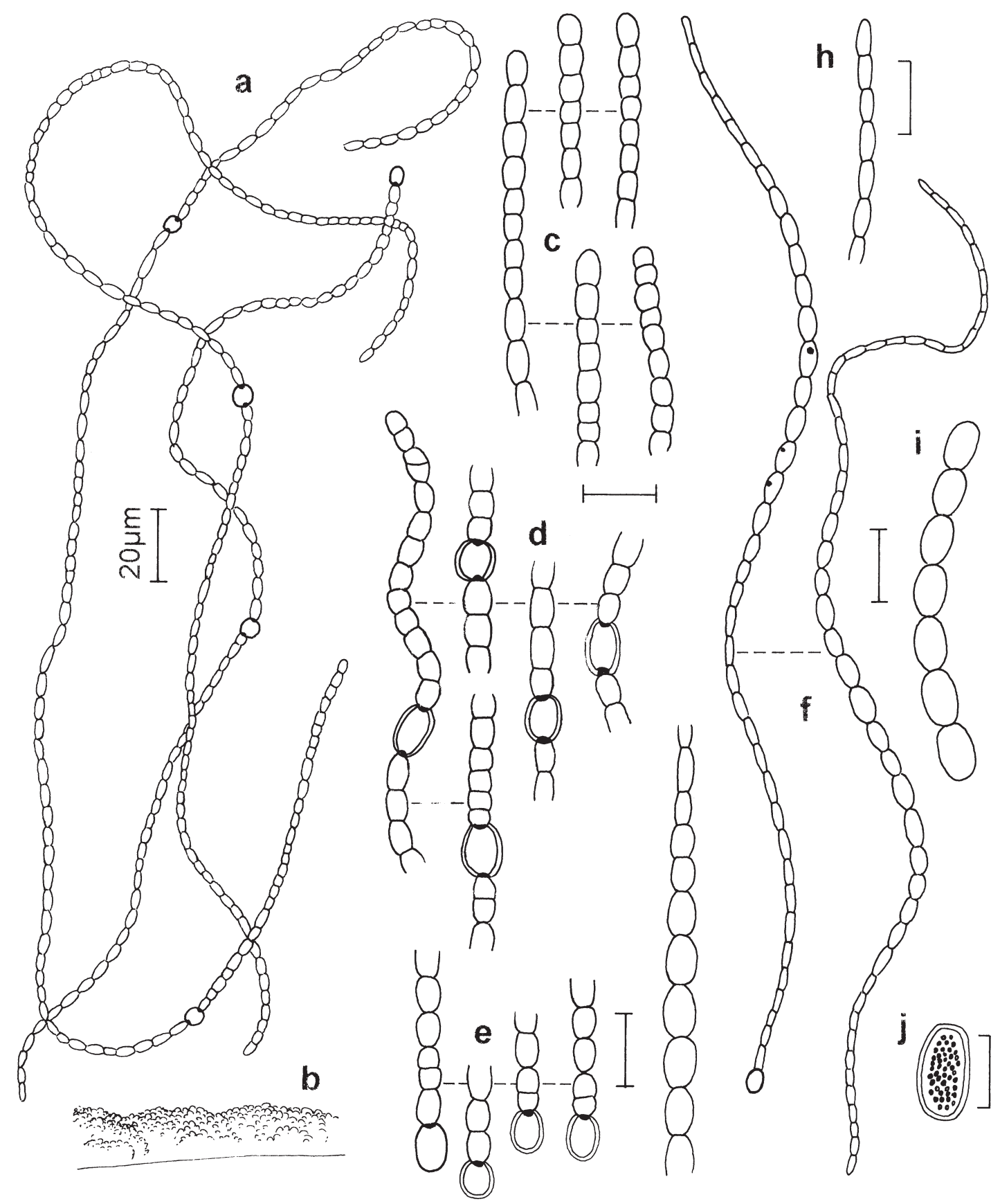

Figure 2a-j. Nostoc viride. a. Few typical trichomes. b. Macroscopic type of colonies (mucilaginous mass). c. End of trichomes. d. Parts of trichomes with intercalary heterocytes. e. Parts of trichomes with terminal heterocytes. f. Two trichmes with developing akinetes. g. Detail of trichome with developing akinetes. h. Terminal part of fertile trichome. i. Chain of liberated akinetes. j. Detail of ripe akinete. Scale bars $=10 \mu \mathrm{m}$, except when indicated. 
formantes, atrovirides vel paucim fuscescentes, ad $1 \mathrm{~cm}$ alta, sine peridermo firmo; trichomatibus dense flexuosis, 4-5 $\mu \mathrm{m}$ latis, ad genicula constricta, ad apices puacim attenuata, cellula apicalis interdum paucim inflata; mucilago sine colore vel lutescens. Cellulae dolliformibus ad cylindricae, plerumque longior quamlatae, rare plus minusve isodiametricae, contentu aerugineo, cum granulis sparsis. Heterocytis solitaris, sphaericis, ovalibus ad cylindricis, 5.2-11 × 4.5$8.5 \mu \mathrm{m}$. Sporis in seriebus longis, ovalis, conentu granuloso, superficie leves, episporio brunescente, 10-12.5 × 6-9 $\mu \mathrm{m}$.

Typus: BRAZIL. São Paulo: São José do Rio Preto, "Universidade Estadual Paulista", 20 47'05" S and 49²1'09" W, 19-XI-2002, L.H.Z. Branco s.n. (holotype SP365629).

Colonies macroscopic, forming mucilaginous, amorphous, dark green mass, up to several $\mathrm{cm}$ in diameter and up to $1 \mathrm{~cm}$ thick, with fine slime, on the surface verrucose, but without distinct periderm. Trichomes constricted, narrowed at the ends, freely irregularly coiled, sometimes forming very densely coiled groups of intensely flexuous filaments inside the colony, 4-5 $\mu \mathrm{m}$ wide. Mucilage colourless or slightly yellowish. Cells barrel-shaped up to cylindrical, usually longer than wide, rarely square, particularly in the terminal parts of trichomes; apical cells sometimes slightly larger, oval. Cell content homogeneous, bluegreen. Heterocytes terminal and intermediate, distinctly longer than vegetative cells, rounded, oval, ovoid or barrel-shaped in intermediate position, terminal heterocytes 4.5-6.2 $\mu \mathrm{m}$ wide, 5.2-8 $\mu \mathrm{m}$ long, intercalar heterocytes 6-8.5 $\mu \mathrm{m}$ wide, $6.5-11 \mu \mathrm{m}$ long. Akinetes in long rows between heterocytes or also in trichomes without heterocytes. Ripe akinetes oval, with granular content, with smooth surface, slightly brownish epispore, 6-9 $\mu \mathrm{m}$ wide, $10-12.5 \mu \mathrm{m}$ long. Reproduction by hormogonia formation not observed. Disintegration of trichomes in solitary cells was commonly observed.

Habitat: macroscopic irregular mats forming slimy layers on wooden substrates in a greenhouse.

Nostoc alatosporum C.L. Sant'Anna et al. sp. nov. Figures 3, 8-9

Coloniae macroscopicae, sphaericae, ad $1 \mathrm{~cm}$ in diametro, aeruginosae, plus minusve cavae, superficie cum peridermo levi; trichomatibus irregulariter flexuosis, cylindricis, ad genicula paucim sed distincte constricta, 2.5-3 $\mu$ m lata. Cellulae longe cylindricae, contentu aerugineo, plus minusve homogeneo vel cum granulis solitariis, 5.2-12.8 um longae; cellula apicalis interdum leve inflata vel claviformis. Heterocytis

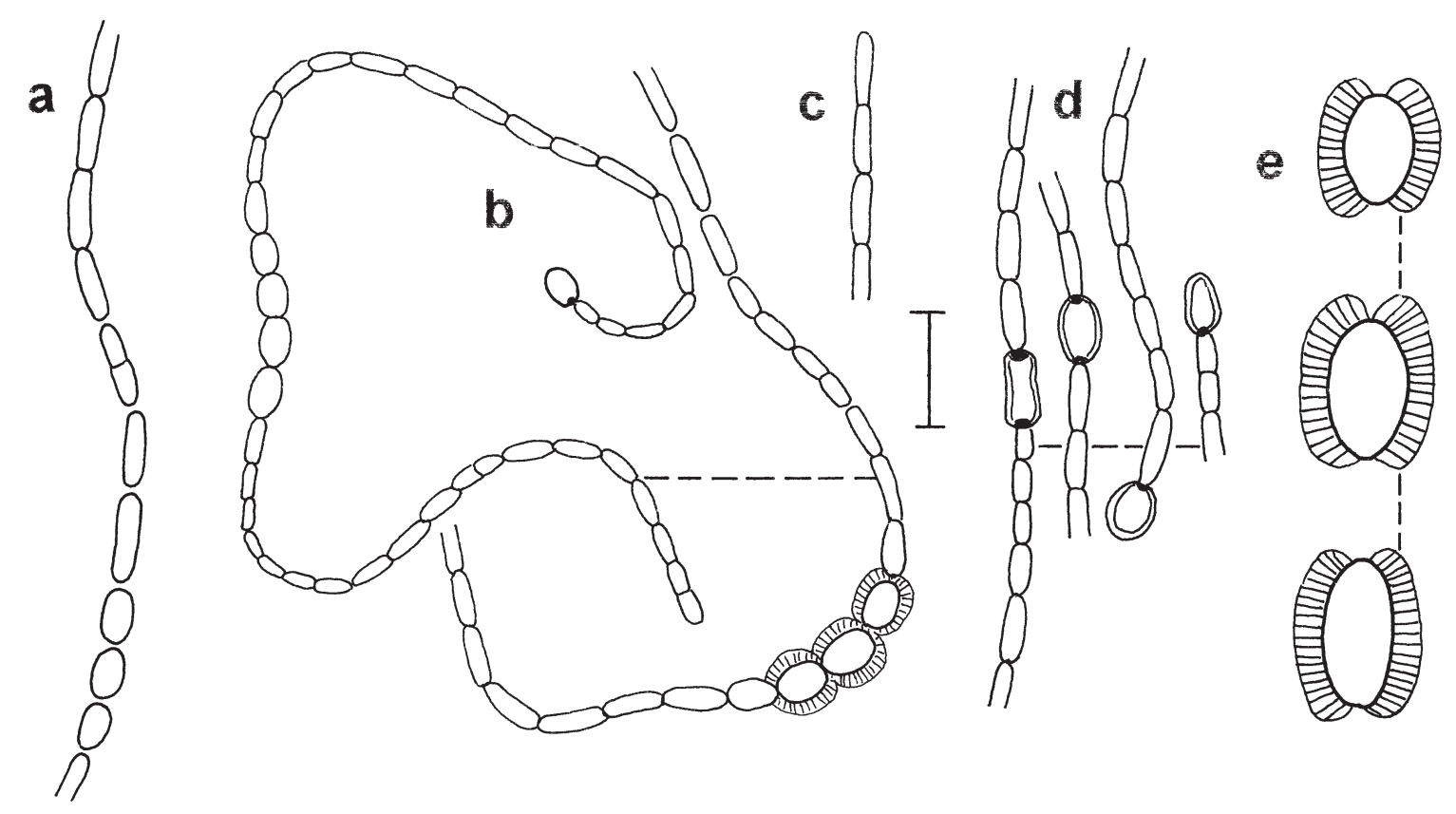

Figure 3a-e. Nostoc alatosporum. a. Part of a trichome with developing akinetes. b. Two trichomes with developing akinetes (ripe akinetes with wide, striated epispore). c. End of a trichome. d. Parts of trichomes with heterocytes. e. Ripe akinetes. Scale bar $=10 \mu \mathrm{m}$. 

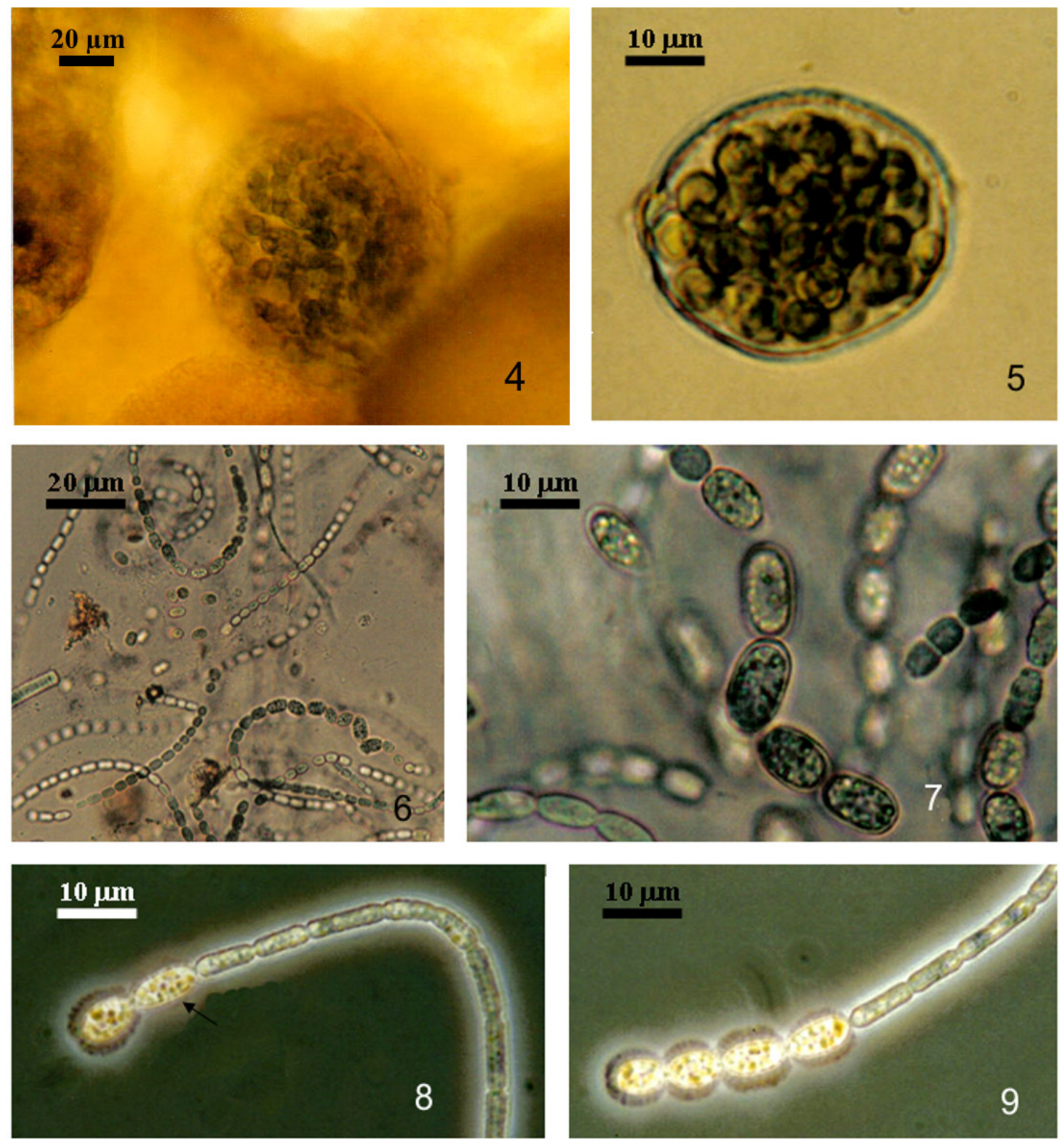

Figures 4-5. Nostoc interbryum. 4. Colony on mosses surface. 5. Trichomes densely aggregated inside the colonial mucilage. Figures 6-7. Nostoc viride. 6. General view of trichomes in the colony. 7. Detail of akinetes chain. Figures 8-9. Nostoc alatosporum. 8. Arrow indicates young akinete without sick epispore. 9. Chain of ripe akinetes. 
subsphaericis, ovalibus vel cylindricis, contentu hyalino vel luteo-virescent. Sporis in seriebus, elliptcis, $8-13 \times 8-10 \mu \mathrm{m}$ (cum episporio), cum endosporio luteo-fusco, episporio lato, achroo, radialiter leve stratoso.

Typus: BRAZIL. São Paulo: Onda Verde, Castores Stream, 20³8'40"'S, 49¹8'29, 9-XI-2002, L.H.Z. Branco s.n. (holotype SP365630).

Colonies macroscopic, more or less spherical, up to $5 \mathrm{~mm}$ (rarely up to $1 \mathrm{~cm}$ ) in diameter, blue-green, hollow, enveloped by a smooth periderm. Trichomes distinctly constricted. Cells cylindrical, 2.5-3 $\mu \mathrm{m}$ wide, 5.2-12.8 $\mu \mathrm{m}$ long. Cell content blue-green, more or less homogeneous. Apical cells cylindrical, rounded or slightly club shaped. Heterocytes terminal and intermediate, solitary, with hyaline, yellowish or greenish content, oval, ovoid, conical, up to cylindrical or with slight constrictions in the middle part. Akinetes in rows, ellipsoidal, 8-13 $\mu$ m wide, 8-10(13) $\mu \mathrm{m}$ long (including widened epispore), with distinct widened, radially striated, colourless epispore when ripe. Reproduction by hormogonia formation and trichomes disintegration not observed.

The morphology of heterocytes and particularly of ripe akinetes is not yet known within the genus Nostoc. Similar widened epispores were described only in the genera Cylindrospermum and benthic species of Anabaena.

Habitat: macroscopic mass on side banks of stream.

\section{Discussion}

The intrageneric taxonomy of the genus Nostoc is very complicated. Particularly the molecular evaluations indicate the heterogeneity of this genus, which will be probably divided in several generic entities (Turner 1997, Rudi et al. 1998, Ventura et al. 2002, Rajaniemi et al. 2005). This revision is closely connected also with revision of ecological and morphological markers, which should coincide with genetic background (Hrouzek et al. 2005). Division of the genus Nostoc in several genera according to morphology of colonies was discussed by several previous authors (Drouet 1977, Elenkin 1936-1949). However, this classification must be revised according to modern data compatible with molecular research. In spite of this prospective trend in cyanobacterial taxonomy, several specific morphotypes have been discovered in various extreme and poorly known habitats in the biosphere (mainly in tropical and subtropical regions). Valid descriptions and presentation of such special morphotypes, which are evidently morphologically and ecologically different from all up to known and described species, are very important for the understanding the cyanobacterial diversity in different ecosystems and regions.

The three morphospecies described from Brazil belong to such special types, which cannot be identified by any existing traditional floras, such as Bornet \& Flahault (1888), Geitler (1932), Elenkin (1936-1949), Desikachary (1959), Kondrateva (1968), and Mollenhauer (1970). The designation of such populations by non-taxonomic terms, is evidently wrong and causes difficulties for scientific progress.

\section{Acknowledgement}

This study was supported by the Brazilian grants FAPESP (02/09349-1) and CNPq (300128/97-5), and by the Czech grants CAS (A6005308 and KSK6005114). The authors also thank Dr. Jefferson Prado, Institute of Botany, for the Latin diagnoses revising.

\section{References}

Bornet, E. \& Flahault, C. 1888. Révision des Nostocacées hétérocystées. Annales des Sciences Naturelles, ser. Botanique, 7: 177-262.

Desikachary, T.V. 1959. Cyanophyta. Indian Council of Agricultural Research, New Delhi.

Drouet, F. 1977. Revision of the Nostocaceae with constricted trichomes. Beihefte zur Nova Hedwigia 57: $1-258$.

Elenkin, A.A. 1936-1949. Monographia algarum cyanophycearum aquidulcium et terrestrium in finibus URSS inventarum [Sinezelenye vodorosli SSSR]. AN SSSR, Moscou.

Geitler, L. 1932. Cyanophyceae. Akademische Verlagsgesellschaft m.b.h., Leipzig.

Hrouzek, P., Ventura, S., Lukesova, A., Mugnai, M.A., Turicchia, S. \& Komárek, J. 2005. Diversity of soil Nostoc strains: phylogenetic and phenotypic variability. Algological Studies 117: 16-122.

Komárek, J. \& Anagnostidis, K. 1989. Modern approach to the classification system of cyanophytes. Nostocales. Algological Studies 56:247-345.

Komárek, J. Komárková, J. \& Kling, H. 2003. Filamentous Cyanobacteria. In: J.D. Wehr \& R.G. Sheath (eds.). Freshwater algae of the United States. Academic Press, Amsterdam, pp. 117-196. 
Kondrateva, N.V. 1968. Sin'o-zeleni vodorosti - Cyanophyta. [Blue-green algae - Cyanophyta]. Vid. "Naukova dumka", Kiev.

Mollenhauer, D. 1970. Beiträge zur Kenntnis der Gattung Nostoc. Abhandlungen der Senckenbergischen Naturforschenden Gesellschaft 524: 1-80.

Rajaniemi, P., Hrouzek, P., Kaštovská, K., Willame, R., Rantala, A., Hoffmann, L., Komárek, J. \& Sivonen, K. 2005. Phylogenetic and morphological evaluation of genera Anabaena, Aphanizomenon, Trichormus and Nostoc (Nostocales, Cyanobacteria). International Journal of Systematic and Evolution Microbiology 55: 11-26.
Rudi, K., Skulberg, O.M. \& Jakobsen, K.S. 1998. Evolution of cyanobacteria by exchange of genetic material among phyletically related strains. Journal of Bacteriology 180: 3453-3461.

Turner, S. 1997. Molecular systematic of oxygenic photosynthetic bacteria. Plant Systematic and Evolution 11: 13-52.

Ventura, S. Mugnai, M.A., Margheri, M.C., Sili, C. \& Turichia, S. 2002. Nostoc, isolation and biodiversity. In: B. Solheim, S. Ventura \& A. Wilmotte (eds.). Cyanobacteria and nitrogen fixation in extreme environments. ESF Cyanofix, Svalbard. 